\title{
Mechanical properties of saccharine sorghum (Sorghum bicolor L. Moench) seeds
}

\author{
Propiedades mecánicas de las semillas de sorgo (Sorghum bicolor L. Moench) \\ Larissa Katiê Moreira Ribeiro ${ }^{1}$, José Henrique Da Silva Taveira ${ }^{1 *}$, Patrícia Costa Silva1, \\ Osvaldo Resende 2 , Daniel Emanuel Cabral De Oliveira ${ }^{3}$, Adriana Rodolfo Costa ${ }^{1}$
}

\begin{abstract}
Study of the mechanical characteristics of agricultural products is crucial to the development of equipment that can achieve the maximum efficiency without compromising the final product quality. Seeds crack and break when exposed to stresses that exceed their resistance to rupture. In this study, we aim to assess the mechanical properties of saccharine sorghum (Sorghum bicolor L. Moench) seeds at different moisture contents. The seeds were harvested in the municipality of Santa Helena - GO, Brazil and indicated an initial moisture content of 0.307 (d.b.). For each moisture content obtained $(0.307,0.258,0.212,0.170,0.130$, and 0.093 d.b.), samples were homogenized and subsequently analyzed. Compressive tests were performed through uniaxial tests in a sample of 15 seeds for each moisture content. In these tests, the "TA Hdi Texture Analyzer" universal testing machine was used, with a 250-N compression load cell. Our results indicated that the compressive force required to deform saccharine sorghum seeds decreased with increasing moisture content, whereas values of proportional modulus of deformity increased with both reduced moisture content and deformation. In addition, the reduction in moisture content caused an increase in the force required to rupture the seeds.

Keywords: proportional modulus of deformity, compression, force to rupture, mechanical damages.
\end{abstract}

\section{RESUMEN}

El estudio de las características mecánicas de los productos agrícolas es importante para que los equipos puedan desarrollarse y lograr la máxima eficiencia sin comprometer la calidad final de los alimentos. Las grietas y roturas de las semillas se producen cuando están expuestas a tensiones que exceden la resistencia del material. El objetivo de este trabajo fue evaluar algunas propiedades mecánicas de las semillas de sorgo de sacarina (Sorghum bicolor L. Moench) con diferentes contenidos de humedad. Las semillas se cosecharon en el municipio de Santa Helena - GO, Brasil, y presentaron un contenido de humedad inicial de 0.307 base seca (b.s.). Para cada contenido de humedad obtenido (0,307; 0,258; 0,212; 0,170; 0,130 y 0,093 b.s.), las muestras fueron homogeneizadas y luego analizadas. Las pruebas de compresión uniaxial se realizaron en una muestra de 15 semillas para cada contenido de humedad. Para esta determinación se utilizó la máquina de prueba universal Analizador de textura TA Hdi, con una celda de carga de compresión de $250 \mathrm{~N}$. Nuestros resultados evidenciaron que la fuerza de compresión necesaria para deformar las semillas de sorgo disminuyó con el aumento del contenido de humedad, mientras que los valores del módulo de deformidad proporcional se incrementaron con la reducción tanto del contenido de humedad como de la deformación. Además, la reducción del contenido de humedad aumentó la fuerza requerida para romper las semillas.

Palabras clave: módulo proporcional de deformidad, compresión, fuerza de ruptura, daños mecánicos.

\section{Introduction}

Sorghum (Sorghum bicolor L. Moench) and some of its current varieties originate from the African continent. Initiatives to introduce this grass in Brazil have previously been performed, however, most efforts from research institutes and universities have been conducted since the 1950s (Purcino, 2011).

\footnotetext{
1 Universidade Estadual de Goiás - Campus Santa Helena de Goiás, Departamento de Engenharia Agrícola, Avenida Protestato Joaquim Bueno, Perímetro urbano, Santa Helena de Goiás - GO, Brasil, Brasil.

2 Instituto Federal Goiano, Rio Verde - GO, Brasil.

3 Instituto Federal Goiano, Iporá - GO, Brasil.

* Autor por correspondencia: jose.taveira@ueg.br
}

Fecha de Recepción: 29 de Mayo, 2019.

Fecha de Aceptación: 31 Julio, 2019. 
Saccharine sorghum is prominent in the sugar-energy sector, since it is a technically and economically viable alternative to replace sugar cane to distilleries, which is their main supply. It prevents the anticipated harvesting of sugarcane in the beginning of the season. It also may be exploited in an integrated farming system, aimed at energy self-sufficiency combined with other agricultural activities (Teixeira et al., 1997).

In the harvesting, drying, handling, transport, and storage periods, seeds undergo a succession of static forces of numerous magnitudes and dynamics, with high-speed impacts that can cause abrasion, crushing, and cracking, thus increasing their vulnerability to deterioration in storage (Bargale et al., 1995).

The mechanical properties of agricultural products must be analyzed to develop equipment that can perform at its maximum capacity without damaging the product final quality. Cracks and breaks occur when the work on the grains exceeds their resistance to damages and rupture (Liu et al., 1990).

Compression studies on three orthogonal axes and four moisture contents in soybean grains confirmed that the highest force that caused rupture occurred when compressive force was perpendicular to cotyledon division. Additionally, resistance and deformation decreased with increasing moisture content (Henry et al., 2000).

Considering the aforementioned information, in this work, we aim to assess the mechanical properties of saccharine sorghum seeds at different moisture contents.

\section{Material and Methods}

An experiment was performed at the State University of Goiás (UEG), in Santa Helena de Goiás - GO, and in the Post-harvest Laboratory of Vegetal Products of the Goiano Federal Institute of Education, Science, and Technology - Rio Verde Campus (IF Goiano - Rio Verde Campus).

Saccharine sorghum (Sorghum bicolor L. Moench) seeds used in this study were harvested in the experimental area of the UEG - Campus Santa Helena with an initial moisture content of 0.307 d.b. The seeds were dried in perforated trays at $50^{\circ} \mathrm{C}$ in a forced-air ventilation oven containing approximately $1 \mathrm{~kg}$ of $5-\mathrm{cm}$ layered product. Reduction in moisture content was monitored by the gravimetric method (weight loss); the initial moisture content of the product was monitored until it reaches the final moisture content of 0.093 d.b., with the aid of a semi-analytical scale of precision $0.01 \mathrm{~g}$.

The moisture content of the seeds was determined by a gravimetric method using a standard hot-air oven with a temperature setting of $105 \pm 3^{\circ} \mathrm{C}$ for $24 \mathrm{~h}$, with two replications (Brasil, 2009). For each obtained moisture content $(0.307,0.258,0.212$, $0.170,0.130$, and 0.093 d.b.), the samples were homogenized and subjected to a compression test.

The compressive force was determined through uniaxial compression tests in a sample of 15 seeds for each obtained moisture content. The experimental tests on the individually analyzed seeds were performed in the "TA Hdi Texture Analyzer" universal testing machine, using a 250-N compression load cell.

The seeds were compressed at their natural resting position, that is, in the thickness direction (smaller axis) (Figure 1) at a constant speed (rate of force application) of $0.001 \mathrm{~m} \cdot \mathrm{s}^{-1}$.

The force-deformation curves obtained were analyzed for the "bioyield point". This point is defined as the position on the force-deformation curve at which an increase in product deformation is associated with a decrease in the compressive force (Figure 2), indicating the beginning of rupture and the structural deformation of the product.

After data acquisition, compressive force curves were constructed as a function of seed deformation for each moisture content studied. Deformations of

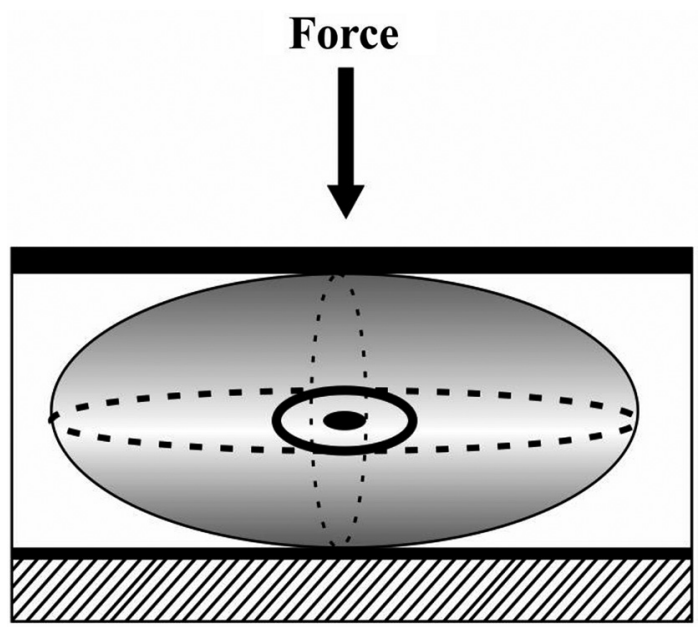

Figure 1. Orientation of saccharine sorghum seeds during the compression tests (smaller axis-thickness) Source: Adapted from Resende et al. (2007). 


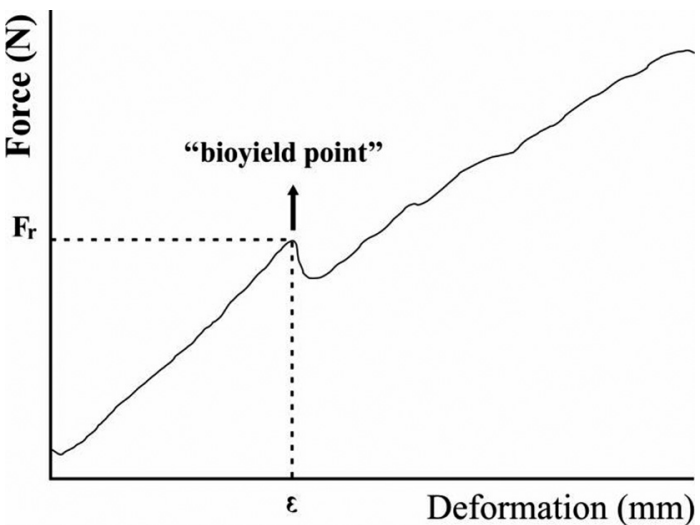

Figure 2. Schematic representation of force-deformation curve, identifying force to rupture $(\mathrm{Sb})$, deformation to rupture $(\varepsilon)$ and "bioyield point".

$0.02,0.04,0.06,0.08,0.10,0.12,0.14,0.16,0.18$, and $0.20 \mathrm{~mm}$ were used.

The proportional modulus of deformity was determined using Eq. 1 according to Batista et al. (2003).

$$
\mathrm{Ep}=\frac{0,531 \times \mathrm{F}}{\mathrm{D}^{3 / 2}} \cdot\left[2 \cdot\left(\frac{1}{\mathrm{r}}+\frac{1}{\mathrm{R}}\right)^{1 / 3}\right]^{3 / 2} .
$$

in which

Ep - proportional modulus of deformity, N. $\mathrm{m}^{-2}$; $\mathrm{F}$ - compressive force, $\mathrm{N}$;

D - total deformation (elastic and plastic) of the body at the contact points with the upper and lower plates, m;

$\mathrm{R}, \mathrm{r}$ - radius of curvature at the contact point, $\mathrm{m}$.

Values of radius of curvature ( $\mathrm{r}$ and $\mathrm{R}$ ) of the seeds at the contact point were obtained through circumferential adjustments to the curvatures of the body, according to the coordinate plane of the compression position, as shown in Figure 3.

The experiment was conducted in a completely randomized design with 10 deformations and six moisture contents. Data were subjected to the analysis of variance and regression. A model was chosen based on the significance of the regression coefficients, using the $t$ test and adopting the 5\% significance level, based on the magnitude of the determination coefficient, relative average error, and knowledge of the evolution of the biological phenomenon.

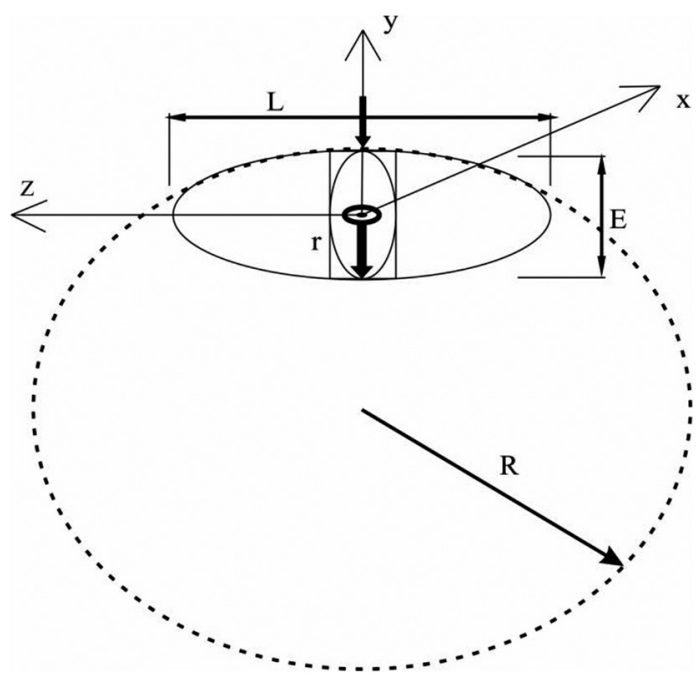

Figure 3. Radius of curvature ( $r$ and $R$ ) of saccharine sorghum seeds in the region of contact between the product and compression plate. $\mathrm{L}=$ length, $\mathrm{E}=$ thickness.

Source: Adapted from Resende et al. (2007)

Finally, the hardness and elasticity of the saccharine sorghum seeds were determined as a function of moisture content. Equation 2 was used, as suggested by Henry et al. (1996) who reported the necessary force to deform biological materials described as a function of deformation according to the Taylor's series:

$$
F=d \cdot x+e \cdot x^{2}+f \cdot x^{3}
$$

in which

$\mathrm{X}$ - deformation, $\mathrm{mm}$;

$\mathrm{d} ; \mathrm{e} ; \mathrm{f}$ - elastic coefficients of the model, units of $\mathrm{N} \cdot \mathrm{mm}^{-1}, \mathrm{~N} \cdot \mathrm{mm}^{-2}$, and $\mathrm{N} \cdot \mathrm{mm}^{-3}$, respectively.

Figure 4 illustrates the force curve versus deformation plotted according to Eq. 1. Using this model allows for the identification of three sections along the curve: the initial concave section, the intermediate section that includes the inflection point, and the convex section in which the slope of the line decreases.

The slope of the force-deformation curve at any point is the tangent $(\mathrm{T})$ and is given by the first derivative of Eq. 3:

$$
T=d+2 e \cdot x+3 f \cdot x^{2}
$$

The maximum tangent is obtained at the inflection point, in which $\mathrm{x}=-e / 3 f$; it is considered 


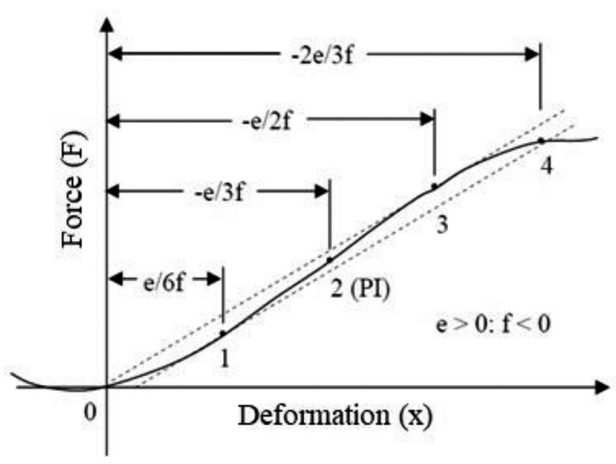

Figure 4. Force curve versus deformation of the model $\mathrm{F}=\mathrm{d}$. $\mathrm{x}+\mathrm{e} \cdot \mathrm{x}^{2}+\mathrm{f} \cdot \mathrm{x}^{3}$; for $\mathrm{e}>0 ; \mathrm{f}<0$; PI $=$ inflection point (Henry et al., 1996).

as an indicator of product hardness. The secant (S), i.e., the slope of the line drawn from the origin to a point on the curve, is expressed as follows (Eq. 4):

$$
S=d+e \cdot x+f \cdot x^{2}
$$

The maximum secant corresponds to the point at which the value of deformation $\mathrm{x}$ is $-e / 2 f$, describing the elasticity at different levels of deformation.

\section{Results and Discussion}

Compressive force curves as a function of deformation for each moisture content in saccharine sorghum seeds are shown in Figure 5. Irrespective of seed moisture content, the compressive force increased with the increase in deformation. To produce the same compression, a higher force was exerted in seeds of lower moisture content. Inflections indicate the beginning of the rupture of the seed coat, that is, the "bioyield point". These results are consistent with those Gupta \& Das (2000), who studied the mechanical properties of sunflower grains.

Figure 6 shows the mean values of the compressive force as a function of moisture content (d.b.) for various deformations. The compressive force required to deform the saccharine sorghum seeds decreased with increasing moisture content and increased with deformation, with values ranging from 0.55 to 47.04 $\mathrm{N}$. These findings are similar to those observed by Fernandes et al. (2014) and Corrêa et al. (2007), who assessed the effect of moisture content on the mechanical properties of wheat and common bean seeds.

Seeds with higher moisture contents are less resistant to compression; compression increases proportionally with the decrease in moisture content and the increase in deformation (Oliveira et al., 2017). According to Gupta \& Das (2000), this tendency may be owing to a gradual change in the cell matrix integrity with the reduction in moisture content.

For the analysis of the proportional modulus of deformity, the values of radius of curvature at the

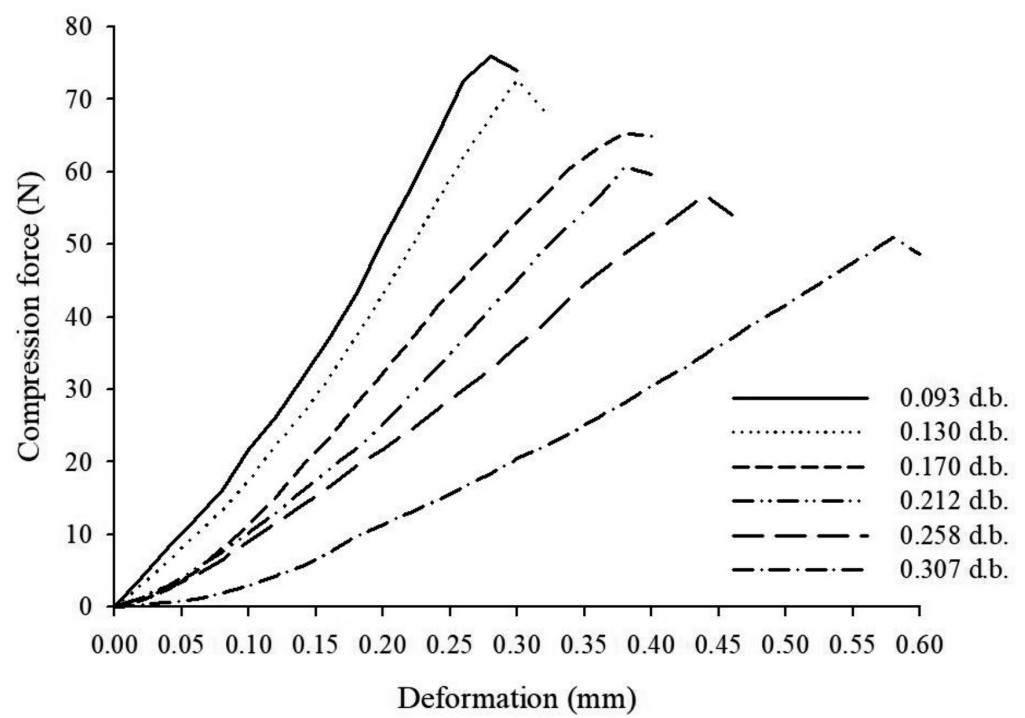

Figure 5. Compressive force $(\mathrm{N})$ as a function of deformation of saccharine sorghum (Sorghum bicolor $\mathrm{L}$. Moench) seeds at different moisture contents 


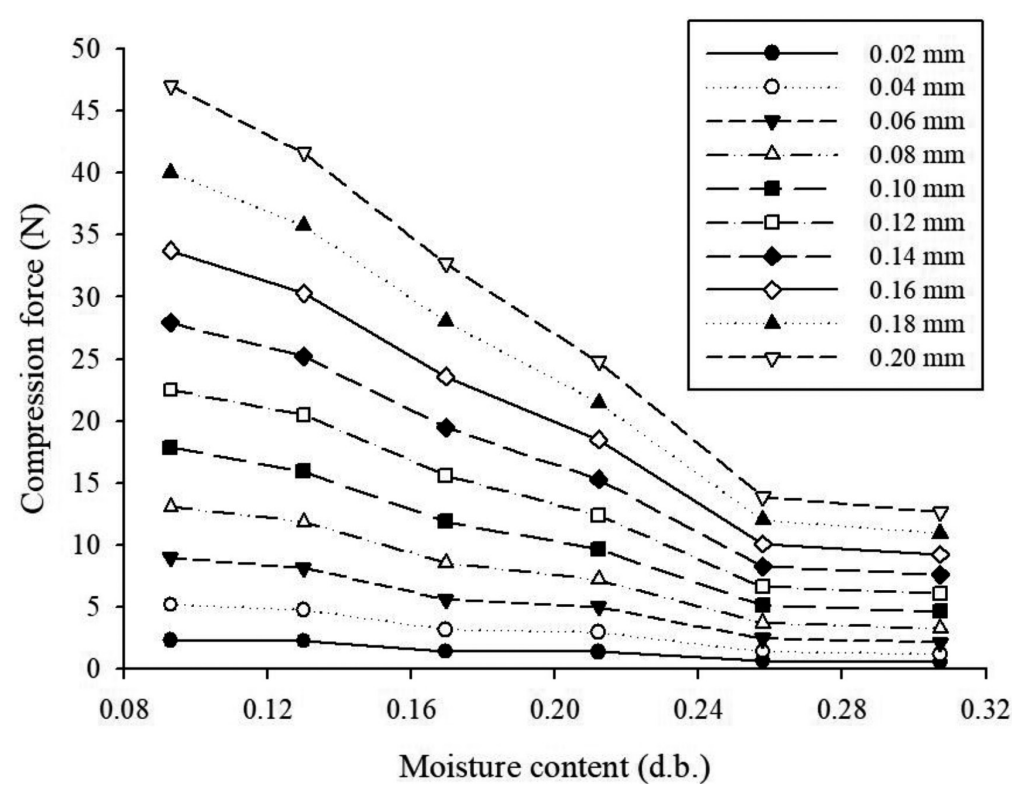

Figure 6. Mean values of compressive force $(\mathrm{N})$ as a function of moisture content (d.b.) for the deformations of $0.02 ; 0.04 ; 0.06 ; 0.08 ; 0.10 ; 0.12 ; 0.14 ; 0.16 ; 0.18$ and $0.20 \mathrm{~mm}$ of saccharine sorghum (Sorghum bicolor L. Moench) seeds.

contact point ( $\mathrm{r}$ and $\mathrm{R}$ ) of 2.93 and 3.42, 2.99 and $3.09,2.58$ and 3.00, 2.77 and 3.16, 2.70 and 3.23, 2.60 and $3.08\left(\times 10^{-3} \mathrm{~m}\right)$ for the moisture contents of $0.307,0.258,0.212,0.170,0.130$, and 0.093 (d.b.), respectively, were used.

Equation 5 was fitted to the data obtained from the proportional modulus of deformity (Ep) of the saccharine sorghum seeds as a function of moisture content (X) and deformation (D). Such an equation displayed a high determination coefficient and is suitable to describe the proportional modulus of deformity.

$$
\begin{aligned}
& \mathrm{Ep}=105,2943-264,1271 X- \\
& 87821,2549 \mathrm{D} \mathrm{R}^{2}=0,9041^{* *}
\end{aligned}
$$

${ }^{* *}$ Significant at $1 \%$ based on the $F$ test.

Figure 7 illustrates the surface response fitted according to Equation 5 obtained for the proportional modulus of deformity of the saccharine sorghum seeds as a function of moisture content and deformation. The values of Ep increased with the decrease in moisture content and deformation, with values ranging from 17.92 to $96.26\left(\times 10^{7} \mathrm{~N} . \mathrm{m}^{-2}\right)$. Resende et al. (2007) and Oliveira et al. (2017) reported a similar trend for typical bean grains and baru fruits, respectively. According to Batista et al. (2003), a high value of the deformity modulus implies that a higher force must be applied to the product to produce a certain deformation.

Ribeiro et al. (2007) reported that the proportional modulus of deformity for soybean grains becomes

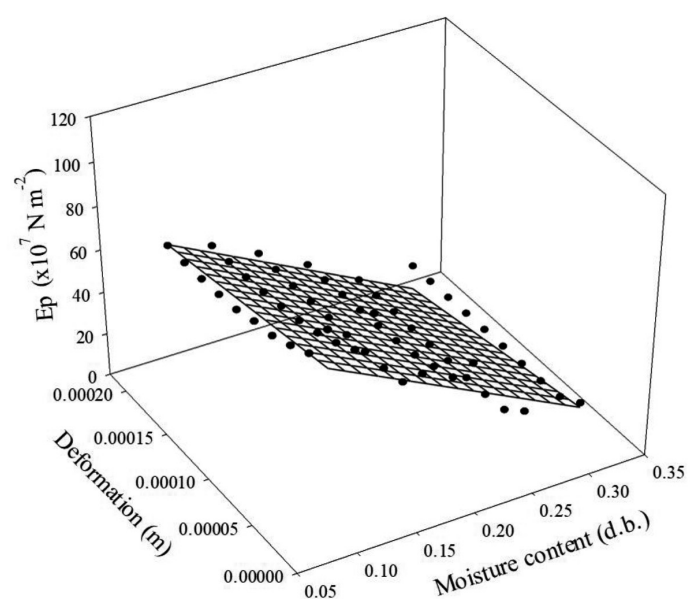

Figure 7. Mean values of the proportional modulus of deformity of saccharine sorghum seeds (Sorghum bicolor L. Moench) as a function of the following deformations: $0.02 ; 0.04 ; 0.06 ; 0.08$; $0.10 ; 0.12 ; 0.14 ; 0.16 ; 0.18$ and $0.20 \mathrm{~mm}\left(\times 10^{-3} \mathrm{~m}\right)$

${ }^{* *}$ Significant at $1 \%$ based on the $F$ test. 
approximately constant for moisture contents higher than 0.22 (d.b.), in contrast to the observations regarding saccharine sorghum seeds in our study.

Table 1 displays the values of elastic coefficients of the model proposed by Henry et al. (1996) (Eq. 2), as well as the values of the maximum tangent and secant at different moisture contents for saccharine sorghum seeds subjected to the compressive test at their natural resting position.

The results indicated that the parameters " $\mathrm{d}$ " and "e" were positive, whereas the parameter " $\mathrm{f}$ " was negative regardless of the moisture content (Table 1). Resende et al. (2007) emphasized that the description of the model presented by Henry et al. (1996) inferred that the signs of the coefficients " $e$ " and " $f$ " represented special conditions of both the material and test. Therefore, the expected signs of the coefficients were positive and negative, represented by "e" and "f," respectively, for undamaged species. Moreover, a positive value for " $\mathrm{d}$ " is always required for a positive initial slope of the line. Indeed, our data were fitted as a sigmoid function irrespective of the moisture content, which is described by Eq. 2 .

The values of the maximum tangent and secant decreased with the reduction in moisture content, whereas the values of the former parameter were higher than those of the maximum secant, consistent with previous studies regarding the mechanical properties of agricultural products similar to ours, as reported by Ribeiro et al. (2007) and Corrêa et al. (2007).

The mean forces to rupture the saccharine sorghum seeds as a function of moisture content are presented in Figure 8.

The reduction in moisture content resulted in a linear increase in the force necessary to achieve the "bioyield point" of the range 78.78-53.10 N. This point represents the beginning of the seed's rupture. Oliveira et al. (2017) reported that such a

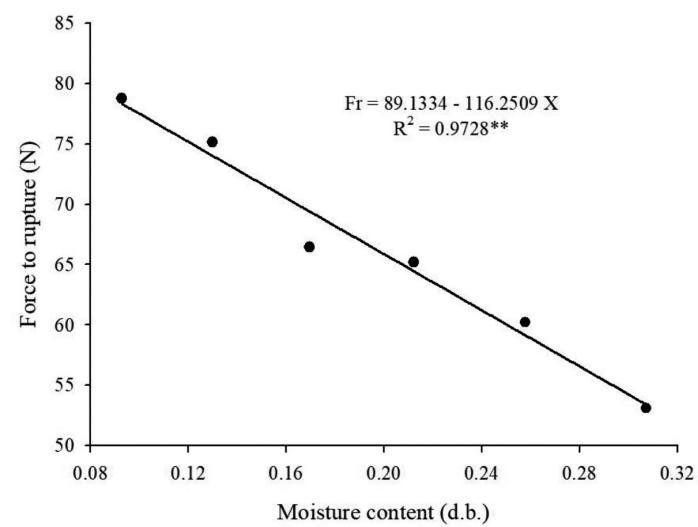

Figure 8. Mean values of force to rupture as a function of moisture content of saccharine sorghum seeds

behavior may be related to a higher cellular density that occurred with water leakage during drying, i.e., number of cells per unit volume increased, thus resulting in a greater resistance to compression at lower moisture contents. Our results were in agreement with those obtained for other agricultural products, including Cuminum cyminum Linn. seeds (Saiedirad et al., 2008), sunflower seeds (Sharma et al., 2009), rough rice (Resende et al., 2013), and baru fruits (Oliveira et al., 2017).

\section{Conclusions}

The compressive force required to deform saccharine sorghum seeds decreased with increasing moisture content.

The values of proportional deformity modulus increased with the reduction in both moisture content and deformation.

Decrease in moisture content increased the force necessary to rupture the seeds.

Table 1. Values of the elastic coefficients $d$, e, f as well as those of the maximum tangent and secant obtained from the force-deformation curve of saccharine sorghum

(Sorghum bicolor L. Moench) seeds at different moisture contents.

\begin{tabular}{cccccc}
\hline $\begin{array}{c}\text { Moisture content } \\
\text { (decimal d.b. })\end{array}$ & $\begin{array}{c}D \\
\left(\mathrm{~N} . \mathrm{mm}^{-1}\right)\end{array}$ & $\begin{array}{c}e \\
\left(\mathrm{~N} . \mathrm{mm}^{-2}\right)\end{array}$ & $\begin{array}{c}F \\
\left(\mathrm{~N} . \mathrm{mm}^{-3}\right)\end{array}$ & $\begin{array}{c}\text { Maximum tangent } \\
\left(\mathrm{N} . \mathrm{mm}^{-1}\right)\end{array}$ & $\begin{array}{c}\text { Maximum secant } \\
\left(\mathrm{N} . \mathrm{mm}^{-1}\right)\end{array}$ \\
0.093 & 107.92 & 712.87 & -403.08 & 528.169 & 423.107 \\
0.130 & 97.08 & 685.01 & -659.68 & 334.185 & 274.909 \\
0.170 & 52.26 & 771.25 & -1085.96 & 234.847 & 189.201 \\
0.212 & 56.73 & 467.30 & -659.16 & 167.153 & 139.547 \\
0.258 & 24.37 & 305.28 & -398.78 & 102.272 & 82.797 \\
0.307 & 17.58 & 342.67 & -570.14 & 86.228 & 69.065 \\
\hline
\end{tabular}




\section{Literature Cited}

Bargale, P.C.; Irudayaraj, J.; Marquis, B. 1995. Studies on rheological behaviour of canola and wheat. Journal Agricultural of Engineering Research, 61: 267-274.

Batista, C.S.; Couto, S.M.; Cecon, P.R.; Peixoto, A.B.

2003. Efeito da temperatura do ar de secagem, do teor de umidade e do estádio de maturação no módulo de deformidade de frutos de café (Coffea arabica L.). Revista Brasil. Brasileira de Armazenamento, 6 (Especial café): 42-53.

2009. Ministério da Agricultura, Pecuária e Abastecimento. Secretaria de Defesa Agropecuária. Regra para análise de sementes. Mapa/ACS. Brasilia, Brasil. 399 p.

Corrêa, P.C.; Resende, O.; Martinazzo, A.P.; Goneli, A.L.D.; Botelho, F.M.

2007. Modelagem matemática para a descrição do processo de secagem do feijão (Phaseolus vulgaris L.) em camadas delgadas. Engenharia Agrícola, 27(2):501-510.

Fernandes, L.S.; Corrêa, P.C.; Diniz, M.D.M.S.; Leite, D.M.; Vasconcellos, D.S.L.

2014. Influência do teor de água nas propriedades mecânicas dos grãos de trigo submetidos à compressão. Biosci. J., 30: 219-223.

Gupta, R.K.; Das, S.K.

2000. Fracture resistance of sunflower seed and kernel to compressive loading. Journal of Food Engineering, Dublin, 46 (1): 1-8.

Henry, Z.A.; Zhang, H.; Onks, D.

1996. Generalized model of resistance to strain of cellular material. American Society of Agricultural Engineers, 96: 1-26.

Henry, Z.A.; Su, B.; Zhang, H.

2000. Resistance of soya beans to compression. Journal of Agricultural Engineering Research, 76 (2): 175-181.

Liu, M.; Haghighi, K.; Stroshine, R.L.; Ting, E.C. 1990. Mechanical properties of soybean cotyledon and failure strength of soybean kernel. Transactions of the American Society of Agricultural Engineers, 33: 559-565.
Oliveira, D.E.C.; Resende, O.; Costa, L.M.; Ferreira Júnior, W.N.; Silva, I.O.F.

2017. Hygroscopicity of baru (Dipteryx alata Vogel) fruit. Revista Brasileira de Engenharia Agrícola e Ambiental, 21 (4): 279-284.

Purcino, A.A.C

2011. Sorgo sacarino na EMBRAPA: histórico, importância e usos. Agroenergia em Revista, Brasília, 2 (3): 6.

Resende, O.; Corrêa, P.C.; Ribeiro, D.M.; Neto, A.F.

2007. Comportamento mecânico de grãos de feijão submetidos a compressão. Revista Brasileira de Engenharia Agrícola e ambiental. Campina Grande, 11 (4): 404-409.

Resende, O.; Corrêa, P.C.; Oliveira, G.H.H.; Goneli, A.L.D.; Jarén, C.

2013. Mechanical properties of rough and dehulled rice during drying. International Journal of Food Studies, 2 (2): 158-166.

Ribeiro, D.M.; Corrêa, P.C.; Furtado, B.F.; Goneli, A.L.D.; Resende, O.

2007. Propriedades mecânicas dos grãos de soja em função do teor de água. Engenharia Agrícola, Jaboticabal, 27 (2): 493-500.

Saiedirad, M.H.; Tabatabaeefar, A.; Borghei, A.; Mirsalehi, M.; Badii, F.; Varnamkhasti, M.G.

2008. Effects of moisture content, seed size, loading rate and seed orientation on force and energy required for fracturing cumin seed (Cuminum cyminum Linn.) under quasi-static loading. Journal of Food Engineering, 86 (4): 565-572.

Sharma, R.; Sogi, D.S.; Saxena, D.C.

2009. Dehulling performance and textural characteristics of unshelled and shelled sunflower (Helianthus annuus L.) seeds. Journal of Food Engineering, 92 (1): 1-7.

Teixeira, C.G.; Jardine J.G.; Beisman; Antônio, D.

1997. Utilização do sorgo sacarino como matéria-prima complementar à cana-de-açúcar para obtenção de etanol em microdestilaria. Ciência e Tecnologia de Alimentos. Campinas, 17 (3): 248-251. 
